\title{
Effect of Bioremediation on early seedling growth of Amaranthus hybridus L. grown on palm oil mill effluent polluted soil
}

\author{
Okon, Okon Godwin *, Elijah, Glory Iniobong \\ Department of Botany and Ecological Studies, University of Uyo, Nigeria \\ *Corresponding author E-mail: okjunior4zeeb@gmail.com
}

\begin{abstract}
The effect of Bioremediation on Early Seedling growth of Amaranthus hybridus L. on oil palm effluent polluted soil was carried out in the field using perforated polythene bags. The soil samples were polluted with $0,80,120$ and $240 \mathrm{ml}$ of oil palm effluent and amended with compost manure supplement (fermented oil palm spikelet) at $0,40,60$ and $80 \mathrm{~g}$ respectively). The $0 \mathrm{ml}$ and $0 \mathrm{~g}$ served as controls. The mean result obtained after 12 weeks showed that the addition of compost manure supplement (fermented oil palm spikelet) to the contaminated soil promotes growth of plant as there was increase in the growth parameters such as shoot height, petiole length, leaf area, number of nodes, number of branches, internode length, root length, and moisture content. This study recommends that contaminated soils should be amended with manure to improve the growth performance of plants.
\end{abstract}

Keywords: Amaranthus, Bioremediation, Effluent, Palm Oil, Pollution and POME.

\section{Introduction}

Palm oil is one of the most important vegetable oil in the world's oil and fat market. The extraction and purification processes generate different kinds of waste generally known as palm oil mill effluent (POME). The environmental impact of POME cannot be over emphasized (Igwe and Onyegbado, 2007). Palm oil mill effluent is the voluminous liquid waste that comes from the sterilisation and clarification sections of the oil palm milling process. The raw effluent contains $90-95 \%$ water and includes residual oil, soil particles and suspended solids (Heuzé et al., 2012). Palm oil mill effluent is a highly polluting material and much research has been dedicated to means of alleviating its threat to the environment Palm oil mill effluent is a highly polluting material, due to its high Biological Oxygen Demand, low pH and colloidal nature. Since the 1980-1990s (depending on the country), developments have taken place in the crude palm oil industry to make this industry environmentally more sustainable (Heuzé et al., 2012). The techniques employed to remove oil pollutants from the environment include physical, chemical and biological methods (Atlas, 1981) (Wang et al., 1994) (Solano-Serena et al., 2000) (Obayori et al., 2008). The physical and chemical methods hardly achieve complete elimination of oil from the environment. The use of chemical method involves application of expensive chemical dispersants, thereby introducing even more pollutants in the environment (Jain et al., 1992). Bioremediation therefore, is indispensable as the most natural method to eliminate the bulk of oil contaminants from the environment (Obidi et al., 2010). In this study, Oil palm spikelet which is relatively cheap and easy to obtain is used as a bioremediating agent to ameliorate oil palm effluent pollution.

\section{Materials and methods}

\subsection{Collection of experimental materials}

Seeds of Amaranthus hybridus used for this study were obtained from the matured plant in the Botanical Garden of the University of Uyo. The soil sample used in this study was obtained from the Department of Botany Postgraduate Research Farm, University of Uyo, Nigeria. The fermented oil palm spikelet used in this study for bioremediation treatment was obtained from an Oil Palm Mill in Ekpene Obom, Etinan Local Government Area, Akwa Ibom State, Nigeria.

\subsection{Physiochemical analysis of the experimental soils}

The physiochemical properties of the experimental soil were evaluated using Atomic Absorption. Spectrotophometer (AAS) (AOAC, 2005). The properties analyzed include: $\mathrm{pH}, \mathrm{Ec}$., organic matter, total nitrogen, available phosphorus, exchangeable calcium, Ex. Potassium. Ex. Acidity, ECEC, bases saturation, silt, clay, Ex. Magnesium, $\mathrm{C} / \mathrm{N}$ ratio, organic carbon and particles size sand. This analysis was carried out on the unpolluted, polluted and the ameliorated soil samples.

\subsection{Pollution of soil samples}

Four kilograms (4 kg) of sterilized loamy soil were weighed using a Mettler (P-165) weighing balance into perforated polythene bags of $38 \mathrm{~cm}$ in width and $40 \mathrm{~cm}$ in length to enhance drainage. Each soil sample was thoroughly mixed with 80,120 and $240 \mathrm{ml}$ of oil palm effluent and incubated for three days (Udo and Oputa, 1984). The unpolluted soil sample served as a control for each treatment (Umoh and Esenowo, 1996).

\subsection{Bioremediation treatment}

Fermented oil palm spikelet was added to the polluted soils (80, 120 and $240 \mathrm{ml}$, at the rate of 40,60 and 80 grammes respectively. The mixture of oil palm effluent, loamy soil and fermented oil 
palm spikelet were left undisturbed for three days to facilitate loosening of the soil constituents (Amadi et al., 1992).

\subsection{Planting of seeds}

Seeds of Amaranthus hybridus were sown directly into perforated polythene bags filled with sterile sandy loam soil at the depth of 5 $\mathrm{cm}$. The experiment was conducted in the field under normal environmental conditions.

\subsection{Determination of growth parameters}

The growth parameters such as plant height (seedling length), petiole length, leaf width and leaf length were measured using meter rule (in centimeter); internode number was also determined. The plants were uprooted during harvest and the root length was measured and moisture content determined.

\subsection{Determination of leaf area}

Leaf Area (LA) was determined by multiplying leaf length by leaf width with the correction co-efficient (r) which is 0.72 (Hoyt and Bradfield, 1962) (Udo and Oputa, 1984).

$$
\mathrm{LA}=\mathrm{L} \times \mathrm{W} \times \mathrm{r}
$$

Where $\mathrm{L}=$ leaf Length

$\mathrm{W}=$ Leaf width

$\mathrm{r}=$ correlation coefficient $(0.72)$

\subsection{Statistical analysis}

Results are expressed as mean \pm Standard Error of Mean (SEM) of three replicates. Statistical significance between the different groups was determined by two-way Analysis of Variance (ANOVA) $\mathrm{P}<0.05$ was considered as statistically significant (Ubom, 2004).

\section{Results}

The physiochemical properties of the soil analysis (Garden soil) indicated that the sandy loamy soil used in this study is rich in available phosphorus, effective cation exchange capacity and organic matter content. The garden soil (unpolluted soil) had a $\mathrm{pH}$ of 6.51. Exchange capacity, silt, clay, exchange Calcium, exchange acidity, exchange Magnesium and organic Carbon, were low while total Nitrogen, exchange Sodium, exchange Potassium and electrical conductivity were relatively low as shown on Table 1. Similarly, the amended soil was also rich in available Phosphorus and it showed slight stimulation in $\mathrm{pH}$ (6.81) with organic supplement (fermented oil palm spikelet). The organic matter content increased, while organic exchange Calcium, exchangeable acidity, silt and clay were low in the soil. Also, the total Nitrogen content (\%), Sodium, Exchange Potassium and Electrical conductivity (EC) were low. the polluted soil imposes low availability of these physiochemical properties as indicated in Table 1.

The results obtained from the growth parameters taken revealed that seedling height of Amaranthus hybridus in polluted soil was $11.90 \pm 0.21,13.10 \pm 2.11,14.40 \pm 0.22$ and $13.13 \pm 0.11$ in $0 \mathrm{ml}$, $80 \mathrm{ml}, 120 \mathrm{ml}$, and 240 respectively. In the same manner, Leaf Area, number of nodes, number of branches, root length and moisture content showed total reduction when compared with the control except in petiole length which had $1.64 \pm 0.41,2.04 \pm 0.13$, $1.60 \pm 0.3,1.60 \pm 0.00$ and $2.03 \pm 0.01 \mathrm{in} 0 \mathrm{ml}, 80 \mathrm{ml}, 120 \mathrm{ml}$ and $240 \mathrm{ml}$ respectively Table 2 .
Table 1: Physiochemical Properties of Experimental Soil

\begin{tabular}{llll}
\hline Soil properties & Garden soil & Polluted soil & Amended soil \\
\hline Ph & 6.81 & 6.60 & 6.81 \\
Organic matter (\%) & 1.98 & 2.46 & 2.86 \\
Total nitrogen (\%) & 0.07 & 0.03 & 0.04 \\
Available P. (mg/kg) & 36.77 & 36.00 & 38.88 \\
Ex. Ca (mol/kg) & 3.25 & 2.66 & 2.82 \\
Ex. N (mol/kg) & 0.07 & 0.02 & 0.04 \\
Ex. K (mol/kg) & 0.94 & 0.15 & 0.18 \\
Ex. Acidity & 3.58 & 2.30 & 2.10 \\
ECEC (mol/kg) & 6.85 & 4.43 & 5.43 \\
Base saturation (\%) & 64.81 & 46.07 & 47.02 \\
Silt (\%) & 4.00 & 2.40 & 2.80 \\
Clay (\%) & 4.20 & 3.20 & 0.60 \\
Ex. Mg (mol/kg) & 1.30 & 0.60 & 0.89 \\
Organic carbon & 1.61 & 0.07 & 0.09 \\
C/N ratio & 91.67 & 94.69 & 98.89 \\
Particle size sand (\%) & 91.80 & 93.80 & 94.00 \\
Ec. (Gs/m) & 0.068 & 0.0364 & 0.0467 \\
\hline Ex- Exchange & & \\
ECEC- Effective Cation Exchange Capacity & \\
EC- Electrical conductivity & & \\
C/N- Carbon/Nitrogen ratio & & \\
& &
\end{tabular}

Table 2: Effects of Palm Oil Mill Effluent Pollution of Soil on the Growth Parameters of Amaranthus Hybridus Seedlings grown for 12 weeks.

\begin{tabular}{|c|c|c|c|c|c|c|c|c|}
\hline $\begin{array}{l}\text { Con } \\
\text { c. } \\
\text { (ml) }\end{array}$ & $\begin{array}{l}\text { Shoo } \\
\mathrm{t} \\
\text { heigh } \\
\mathrm{t} \\
(\mathrm{cm})\end{array}$ & $\begin{array}{l}\text { Peti- } \\
\text { ole } \\
\text { lengt } \\
\text { h } \\
(\mathrm{cm})\end{array}$ & $\begin{array}{l}\text { Leaf } \\
\text { Ar- } \\
\text { ea } \\
\left(\mathrm{cm}^{2}\right. \\
)\end{array}$ & $\begin{array}{l}\text { Num- } \\
\text { ber of } \\
\text { nodes }\end{array}$ & $\begin{array}{l}\text { Num- } \\
\text { ber of } \\
\text { branch } \\
\text { es }\end{array}$ & $\begin{array}{l}\text { Inter- } \\
\text { node } \\
\text { length } \\
(\mathrm{cm})\end{array}$ & $\begin{array}{l}\text { Root } \\
\text { lengt } \\
\mathrm{h} \\
(\mathrm{cm})\end{array}$ & $\begin{array}{l}\text { Mois- } \\
\text { ture } \\
\text { content } \\
\text { (g) }\end{array}$ \\
\hline 0 & $\begin{array}{l}11.90 \\
\pm \\
0.21\end{array}$ & $\begin{array}{l}1.64 \\
\pm \\
0.41\end{array}$ & $\begin{array}{l}5.04 \\
\pm \\
0.22\end{array}$ & $\begin{array}{l}32.0 \pm \\
0.00\end{array}$ & $\begin{array}{l}24.0 \pm \\
0.00\end{array}$ & $\begin{array}{l}1.55 \pm \\
2.11\end{array}$ & $\begin{array}{l}11.9 \\
0 \pm \\
0.07\end{array}$ & $\begin{array}{l}2.81 \pm \\
0.08\end{array}$ \\
\hline 80 & $\begin{array}{l}13.10 \\
\pm \\
2.11\end{array}$ & $\begin{array}{l}2.04 \\
\pm \\
0.13\end{array}$ & $\begin{array}{l}4.86 \\
\pm \\
0.12\end{array}$ & $\begin{array}{l}27.0 \pm \\
0.00\end{array}$ & $\begin{array}{l}21.0 \pm \\
0.00\end{array}$ & $\begin{array}{l}2.14 \pm \\
1.12\end{array}$ & $\begin{array}{l}10.1 \\
3 \pm \\
0.24\end{array}$ & $\begin{array}{l}2.60 \pm \\
1.22\end{array}$ \\
\hline 120 & $\begin{array}{l}14.40 \\
\pm \\
0.22\end{array}$ & $\begin{array}{l}1.60 \\
\pm \\
0.00\end{array}$ & $\begin{array}{l}4.17 \\
\pm \\
0.11\end{array}$ & $\begin{array}{l}14.0 \pm \\
0.00\end{array}$ & $\begin{array}{l}16.0 \pm \\
0.00\end{array}$ & $\begin{array}{l}1.72 \pm \\
1.00\end{array}$ & $\begin{array}{l}6.0 \\
\pm \\
0.28\end{array}$ & $\begin{array}{l}1.82 \pm \\
0.78\end{array}$ \\
\hline 240 & $\begin{array}{l}13.13 \\
\pm \\
0.11\end{array}$ & $\begin{array}{l}2.03 \\
\pm \\
0.01\end{array}$ & $\begin{array}{l}3.28 \\
\pm \\
0.01\end{array}$ & $\begin{array}{l}9.0 \pm \\
0.00\end{array}$ & $\begin{array}{l}13.0 \pm \\
0.00\end{array}$ & $\begin{array}{l}1.53 \pm \\
0.24\end{array}$ & $\begin{array}{l}7.6 \\
\pm \\
0.05\end{array}$ & $\begin{array}{l}1.50 \pm \\
0.47\end{array}$ \\
\hline
\end{tabular}

Data were processed and expressed as mean \pm SD of three replicates.

In amended soil, the results showed that the growth parameters tested were stimulated above the control, seedling height was $11.90 \pm 0.27,20.71 \pm 0.20,18.60 \pm 0.10$ and $18.10 \pm 0.00$ in $0 \mathrm{ml}$, $80 \mathrm{ml}, 120 \mathrm{ml}, 240 \mathrm{ml}$. Other parameters showed the same increase except in moisture content which showed stimulation in $240 \mathrm{ml}$ above lower concentration, i.e. $2.81 \pm 0.00,3.87 \pm 0.21,3.98 \pm$ 0.81 and $4.00 \pm 0.78$ in $0,80,120$, and $240 \mathrm{ml}$ respectively. It was also observed that, the higher the concentration of POME pollution, decrease in growth parameters was observed as indicated on Table 3.

Table 3: Effects of Bioremediation Treatment on the Growth Parameters of Amaranthus Hybridus Seedlings grown for 12 Weeks.

\begin{tabular}{|c|c|c|c|c|c|c|c|c|}
\hline $\begin{array}{l}\text { Con } \\
\text { c. } \\
\text { (ml) }\end{array}$ & $\begin{array}{l}\text { Shoo } \\
\mathrm{t} \\
\text { heig } \\
\text { ht } \\
(\mathrm{cm})\end{array}$ & $\begin{array}{l}\text { Peti- } \\
\text { ole } \\
\text { lengt } \\
\text { h } \\
\text { (cm) }\end{array}$ & $\begin{array}{l}\text { Leaf } \\
\text { area } \\
(\mathrm{cm} \\
\left.{ }^{2}\right)\end{array}$ & $\begin{array}{l}\text { Num- } \\
\text { ber of } \\
\text { nodes }\end{array}$ & $\begin{array}{l}\text { Num- } \\
\text { ber of } \\
\text { branch } \\
\text { es }\end{array}$ & $\begin{array}{l}\text { Inter- } \\
\text { node } \\
\text { length } \\
(\mathrm{cm})\end{array}$ & $\begin{array}{l}\text { Root } \\
\text { lengt } \\
\mathrm{h} \\
(\mathrm{cm})\end{array}$ & $\begin{array}{l}\text { Mois- } \\
\text { ture } \\
\text { content } \\
\text { (g) }\end{array}$ \\
\hline 0 & $\begin{array}{l}11.9 \\
0 \pm \\
0.27\end{array}$ & $\begin{array}{l}1.64 \\
\pm \\
0.00\end{array}$ & $\begin{array}{l}5.04 \\
\pm \\
0.08\end{array}$ & $\begin{array}{l}32.0 \pm \\
0.00\end{array}$ & $\begin{array}{l}24.0 \pm \\
0.00\end{array}$ & $\begin{array}{l}1.55 \pm \\
0.28\end{array}$ & $\begin{array}{l}11.9 \\
0 \pm \\
0.56\end{array}$ & $\begin{array}{l}2.81 \pm \\
0.00\end{array}$ \\
\hline 80 & $\begin{array}{l}20.7 \\
1 \pm \\
0.20\end{array}$ & $\begin{array}{l}2.84 \\
\pm \\
0.28\end{array}$ & $\begin{array}{l}10 \\
52 \pm \\
0.22\end{array}$ & $\begin{array}{l}38.0 \pm \\
0.00\end{array}$ & $\begin{array}{l}32.0 \pm \\
0.00\end{array}$ & $\begin{array}{l}2.62 \pm \\
0.71\end{array}$ & $\begin{array}{l}18.8 \\
\pm \\
0.18\end{array}$ & $\begin{array}{l}3.87 \pm \\
0.21\end{array}$ \\
\hline 120 & $\begin{array}{l}18.6 \\
0 \pm \\
0.10\end{array}$ & $\begin{array}{l}2.88 \\
\pm \\
0.24\end{array}$ & $\begin{array}{l}8.42 \\
\pm \\
0.11\end{array}$ & $\begin{array}{l}29.0 \pm \\
0.00\end{array}$ & $\begin{array}{l}29.0 \pm \\
0.00\end{array}$ & $\begin{array}{l}1.98 \pm \\
2.00\end{array}$ & $\begin{array}{l}17.2 \\
\pm \\
0.00\end{array}$ & $\begin{array}{l}3.98 \pm \\
0.81\end{array}$ \\
\hline 240 & $\begin{array}{l}10.1 \\
0 \pm \\
0.00\end{array}$ & $\begin{array}{l}2.60 \\
\pm \\
0.00\end{array}$ & $\begin{array}{l}6.81 \\
\pm \\
1.28\end{array}$ & $\begin{array}{l}26.0 \pm \\
0.00\end{array}$ & $\begin{array}{l}27.0 \pm \\
0.00\end{array}$ & $\begin{array}{l}1.82 \pm \\
1.87\end{array}$ & $\begin{array}{l}15.8 \\
\pm \\
1.22\end{array}$ & $\begin{array}{l}4.80 \pm \\
0.78\end{array}$ \\
\hline
\end{tabular}

Data were processed and expressed as mean \pm SD of three replicates.

\section{Discussion}

Palm oil effluent like any other oil products adversely affects the growth and performances of plants as indicated in the results got- 
ten from this study. The effect of palm oil mill effluent on the seedling height observed here were similar to those reported on the effect of spent engine oil on Amaranthus hybridus (Odjegba and Sadiq, 2002). Njoku et al. (2008) reported same observation on the effect of crude oil on the growth of Glycine max and Lycopersicon esculentum. Adedokum and Ataya (2007) also showed that treatment of soils with crude oil, automotive gasoline oil and spent engine oil significantly affect the time of germination, percentage germination, plant height, leaf production and biomass of Vigna unguiculata delaying germination and growth rate. Similarly, Okon et al. (2012) concluded that at high concentrations of crude oil, growth yield and tubers production of Manihot esculenta were hindered but organic supplements (chicken droppings) were found to reduce the toxic effects of crude oil thereby stimulating the yield of cassava.

The leaf surface area determines in large part the amount of carbon gained through photosynthesis and the amount of water lost through transpiration and ultimately the crop yield (Kathirvelan and Kalaiselvan, 2007). Therefore, the reduction observed in this study implies that there would be lower contact of photosynthetic efficiency of the plant as much of the solar energy emitted by sun would not be absorbed by plant for photosynthesis. This can lead to low performance of the plant (Amaranthus hybridus) with subsequent low availability of food and poor economy due to low sales of such plants products. Availability of nitrogen in the soil directly affects the relative growth rate of plants (Walker et al., 2001). Since oil products are known to reduce nitrogen availability (Agbogidi et al., 2007), this could be the cause of adverse effect on the plant growth parameters with increase in the palm oil effluent. The growth parameter in this study showed a significant $(\mathrm{P}<0.05)$ stimulation with the addition of nutrient supplements because it has been shown that plants grow slower under low nutrient (Grotkopp and Rejmanek, 2007). Proper growth of cultivated plants depends on the content of nutrients in the soil (Wyszkowski and Zoilkowska, 2008). Okon et al. (2013) also reported that nutrient amendment in poor soil successfully improved the soil quality, germination and yield component of two varieties of Okra (Abelmoschus esculentus); they added that the use of organic manure is therefore necessary in poor nutrient soils.

\section{Conclusion}

This study showed that palm oil mill effluent contamination of soil may result in low soil fertility. As shown in this study, this effect can be remedied by the addition of compost manure supplements especially fermented oil palm spikelet and the quantity of the supplement added has significant effect on the remediation process of the soil. Moreover, it can be deduced from this research that plants can perform relatively better in palm oil effluent polluted agricultural soil if such soil is amended with reasonable quantity of manure.

\section{Acknowledgement}

We want to appreciate Mr. Ini-obong of Soil Science Laboratory, Soil science Department, and University of Uyo, Nigeria.

\section{References}

[1] Adedokun, O. M. and Ataya, A. E. (2007). Effects of Amendment and bioaugmentation of soil polluted with crude oil, automotive gasoline oil and spent engine oil on the growth of cowpea (Vigna unguiculata L. Walp). Scientific Research and Essays, 2(5):147-149.

[2] Agbogidi, O. M., Eruotor P.G., Akparabi S.O., (2007). Effects of time of application of crude oil to soil on the growth of maize (Zea mays L.). Research Journal of Environmental Toxicology. 1(3): 116-123. http://dx.doi.org/10.3923/rjet.2007.116.123.

[3] Amadi, A., Dickson, A. A. and Maarie, G. O. (1992). Remediation of oil Polluted Soils. Air, Water and Soil Pollution, 66: 59-76. http://dx.doi.org/10.1007/BF00477060.
[4] AOAC (2005). Official methods of Analysis, 18th ed. Association of Analytical Chemists. Washington D.C, USA, pp. 78-87.

[5] Atlas RM (1981). Microbial degradation of petroleum hydrocarbons: An environmental perspective. Microbiology Reviews, 45: 180-200.

[6] Grotkopp, E. and Rejmanek, M. (2007). High seedling relative growth rate and specific leaf area are traits of invasive species: Phytogenetically independent contrasts of woody angiosperms. American Journal of Botany, 94:526-532. http://dx.doi.org/10.3732/ajb.94.4.526.

[7] Heuzé V., Tran G., Bastianelli D., Lebas F. (2012). Palm oil mill effluent. Feedipedia.org. A programme by INRA, CIRAD, AFZ and FAO. http://www.feedipedia.org/node/15395 last updated on June 2, 2012, 21:47.

[8] Hoyt, P. and Bradfield, R. (1962). Effect of varying leaf by defoliation and plants density on dry matter production on corn. Agronomy Journal, $\quad 54$ : $\quad 523 \quad 525$. http://dx.doi.org/10.2134/agronj1962.00021962005400060017x.

[9] Igwe J.C. and Onyegbado C.C. (2007). A Review of Palm Oil Mill Effluent (Pome) Water Treatment. Global Journal of Environmental Research, 1(2): 54-62, 2007.

[10]Jain DK, Lee H, Trevors T (1992) Effect of addition of Pseudomonas aeruginosa UG2 inocula or biosurfactants on biodegradation of selected hydrocarbons in soils. Journal of Industrial Microbiology, 10: 87-93. http://dx.doi.org/10.1007/BF01583840.

[11]Kathirvelan, P. and Kalaiselvan, P. (2007). Groundnut (Arachis hypogaea L.) leaf area estimation using allometric model. Research Journal of Agriculture and Biological Science, 3(1): 59-61.

[12] Njoku, K. L., Akinola, M. O. and Oboh, B. O. (2008). Germination, survival and growth of accession of Glycine max L. (Merril) (soybean) and Lycopersicon esculentum L. (Tomato) in crude oil polluted soil. Research Journal of Environmental Toxicology, 2(2):77-84 http://dx.doi.org/10.3923/rjet.2008.77.84.

[13] Obayori OS, Ilori M. O., Adebusoye S. A., Amund O. O., Oyetibo G. O. (2008) Microbial population changes in tropical agricultural soil experimentally contaminated with crude petroleum. African Journal of Biotechnology, 7(24): 4512-4520.

[14] Obidi O. F., Onuoha A. C. and Nwachukwu S. C. (2010). Bioremediation of Crude Petroleum Polluted Stagnant Water with Fermented Cassava Steep. Report and Opinion, 2010; 2 (11).

[15] Odjegba, V. and Sadiq, A. O. (2002). Effects of spent engine oil on the growth parameters, chlorophyll and protein levels of Amaranthus hybridus L. The Environmentalist, 22:23-28. http://dx.doi.org/10.1023/A:1014515924037.

[16]Okon, J. E., Esenowo, G. J. and Umoh, N. S. (2012). Effects of crude oil pollution of soil and amelioration treatment on the growth of eight varieties of Manihot esculenta Grantz. International Journal of Chemical Environmental and Pharmaceutical Research, 3(2):163-169.

[17]Okon, J. E., Mbong, E. O., Ebukanson, G. J. and Uneh, O. H. (2013). Influence of nutrient amendments of soil quality on germination, growth and yield components of two varieties of okra (Abelmoschus esculentus (L.) Moench) sown at University of Uyo Botanical Garden, Uyo, Akwa Ibom State. E3 Journal of Environmental Research Management, 4(3):0209-0213.

[18]Solano-Serena F, Marchal R, Lebeault JM, Vandecasteele JP (2000) Selection of microbial population degrading recalcitrant hydrocarbons of gasoline by monitoring of culture-headspace composition. Letter of Applied Microbiology 30: 19-22. http://dx.doi.org/10.1046/j.1472765x.2000.00631.x

[19]Ubom, R.M. (2004). Biometry. Uyo: Abraam Publishers, pp. 12 - 58.

[20]Udo, E. J. and Oputa C. O. (1984). Journal of Biology and Applied Chemistry. (11) 26

[21]Umoh, N. S. and Esenowo, G. J. (1996). Trans-Nigeria Society Biological Conservation, (5) 700 .

[22]Walker, R. L., Burns, I. G. and Moorby, I. (2001). Response of plant growth rate to Nitrogen supply: A comparison of relative addition and nitrogen interruption treatment. Journal of Experimental Botany, 52(355):309-317. http://dx.doi.org/10.1093/jexbot/52.355.309.

[23] Wang Z, Fingas M, Sergy G (1994) Study of 22 year-old Arrow oil samples using biomaker compounds by GC/MS. Environmental Sci$\begin{array}{lll}\text { ence } \quad \text { and } & \text { 1733-1746. }\end{array}$ http://dx.doi.org/10.1021/es00058a027.

[24]Wyszkowski, M. and Zoilkowska, A. (2008). Effects of petrol and Diesel oil on content of organic carbon and mineral components in soil. American-European Journal of Sustainable Agriculture, 2(1):5460 